\title{
Quercetin Induces Mitochondrial Mediated Apoptosis and Protective Autophagy in Human Glioblastoma U373MG Cells
}

\author{
Hyeonji Kim, ${ }^{1}$ Jeong Yong Moon, ${ }^{1,2}$ Kwang Seok Ahn, ${ }^{3}$ and Somi Kim Cho ${ }^{1,2}$ \\ ${ }^{1}$ Faculty of Biotechnology, College of Applied Life Sciences, Jeju National University, 66 Jejudaehakno, Jeju 690-756, Republic of Korea \\ ${ }^{2}$ Subtropical Horticulture Research Institute, Jeju National University, Jeju 690-756, Republic of Korea \\ ${ }^{3}$ Department of Oriental Pathology, College of Oriental Medicine, Kyung Hee University, 1 Hoegi-Dong dongdaemun-gu, \\ Seoul 130-701, Republic of Korea
}

Correspondence should be addressed to Kwang Seok Ahn; ksahn@khu.ac.kr and Somi Kim Cho; phd.kim.somi@gmail.com

Received 5 August 2013; Revised 16 October 2013; Accepted 28 October 2013

Academic Editor: Tullia Maraldi

Copyright (C) 2013 Hyeonji Kim et al. This is an open access article distributed under the Creative Commons Attribution License, which permits unrestricted use, distribution, and reproduction in any medium, provided the original work is properly cited.

Quercetin is a dietary flavonoid with known antitumor effects against several types of cancers by promoting apoptotic cell death and inducing cell cycle arrest. However, U373MG malignant glioma cells expressing mutant p53 are resistant to a $24 \mathrm{~h}$ quercetin treatment. In this study, the anticancer effect of quercetin was reevaluated in U373MG cells, and quercetin was found to be significantly effective in inhibiting proliferation of U373MG cells in a concentration-dependent manner after 48 and $72 \mathrm{~h}$ of incubation. Quercetin induced U373MG cell death through apoptosis, as evidenced by the increased number of cells in the subG1 phase, the appearance of fragmented nuclei, decreased mitochondrial membrane potential, proteolytic activation of caspase-3 and caspase-7, an increase in caspase- 3 and 9 activities, and degradation of poly(ADP-ribose) polymerase protein. Furthermore, quercetin activated JNK and increased the expression of p53, which translocated to the mitochondria and simultaneously led to the release of cytochrome $\mathrm{c}$ from mitochondria to the cytosol. We also found that quercetin induced autophagy. Pretreatment with chloroquine, an autophagy inhibitor, strongly augmented apoptosis in U373MG cells, indicating that quercetin induced protective autopagy in U373MG cells.

\section{Introduction}

Glioblastoma is the most common type of primary brain tumor in adults and the most lethal and least successfully treated tumor. The low absolute incidence combined with high morbidity, poor response rate, and short survival time poses practical problems for clinical trial execution [1]. Less than $30 \%$ of patients suffering from this devastating disease survive 12-15 months, even after receiving multimodal treatments such as surgical resection, combined chemotherapy and radiotherapy, and adjuvant chemotherapy [2]. These observations underscore the need for alternative therapies to prevent and effectively treat glioblastoma.

Quercetin is an antioxidative flavonoid ubiquitously distributed in plants. Its anticancer effects have been attributed to antioxidative activity, inhibition of enzymes activating carcinogens, modification of signal transduction pathways, and interactions with receptors and other proteins [3]. Quercetin is an anticancer agent in many cancer models [4-12]. Several studies have reported that quercetin increases the efficacy of glioblastoma treatment by suppressing the PI-3-kinaseAkt pathway [13], inducing apoptosis by reducing X-linked inhibitor of apoptosis protein (XIAP) [14], blocking signal transducer and activator of transcription 3 (STAT3) [15], arresting cells at the G2 checkpoint of the cell cycle, and decreasing the mitotic index in glioma cells [16]. Such effects of quercetin in glioblastoma cells seem to be dependent on cell type because combined application of tumor necrosis factor-related apoptosis-inducing ligand (TRAIL) and quercetin strongly reduces viability of U87MG, U251, A172, and LN229 glioma cells but fails to reduce the viability of U373MG cells [17]. The cause of U373MG cell resistance to quercetinTRAIL-mediated apoptosis is not fully understood. Inactivating p53 is not important in quercetin-TRAIL-mediated 
apoptosis, as both sensitive $\mathrm{U} 251$ and the completely resistant U373MG cells have p53 mutations.

Apoptosis is programmed cell death mediated by caspases, which are cysteine proteases that cleave target proteins at aspartic acid. p53 is a transcription factor that induces the expression of proapoptotic genes [18, 19], and activating apoptosis is an important mechanism in p53-induced tumor suppression. Mitochondrial localization of mutant p53 and evidence linking p53 transcription-independent or mitochondria-targeted apoptosis has received considerable attention. A fraction of p53 translocates to mitochondria prior to changes in the mitochondrial membrane potential, cytochrome c release, and activation of caspases [20-22]. A previous study suggested that cellular cross-talk may occur between mitochondrial and nuclear p53. Heyne et al. [23] suggested that mutant p53 exists as a monomeric protein in mitochondria, and Tang et al. [24] demonstrated that mutant p53 translocates to mitochondria in UVB-irradiated murine skin carcinoma cells. Mahyar-Roemer et al. [25] suggested that mutant p53 is present in mitochondria independent of apoptotic signals. Mihara et al. [26] reported that p53 binds to $\mathrm{Bcl}-\mathrm{xL}$ via its DNA-binding domain and that mutant $\mathrm{p} 53$ $\mathrm{R} 273 \mathrm{H}$ cannot bind $\mathrm{Bcl}-\mathrm{xL}$ and is therefore unable to activate the direct mitochondrial pathway of apoptosis despite being localized in or at the mitochondria. However, mutant p53 can also induce apoptosis through a transcription-independent pathway, in which wild-type p53 and p53 mutants are transiently located to the mitochondria with changes in the mitochondrial membrane potential [27]. Furthermore, a few such transcriptionally impaired p53 mutants (e.g., the structural mutant $\mathrm{R} 175 \mathrm{H}$ and the DNA contact mutants $\mathrm{R} 273 \mathrm{H}$ and C277F) bind Bak in vitro, and this is correlated with their ability to oligomerize Bak and induce cytochrome $\mathrm{c}$ release from isolated mitochondria [28]. We questioned whether mutant p53 R273H affects mitochondrial functions in human glioma blastoma cells.

Here, we addressed the question of whether autophagy is intimately linked with apoptosis induced by quercetin in U373MG cells. Autophagy is an evolutionarily conserved and genetically programmed process that degrades long-lived cellular proteins and organelles. The role of autophagy in cancer is quite complicated and controversial. Autophagy is assumed to be tumor suppressive during cancer development but to contribute to tumor cell survival during cancer progression [29]. Alternatively, autophagy prevents tumor cells from dying by inhibiting apoptosis during nutritional deprivation, and the cells undergo apoptosis when autophagy is prevented [30-32]. Regardless of whether they promote cell survival or cell death, the two processes engage in complex and poorly understood molecular cross-talk [33] and inducing apoptosis and inhibiting protective autophagy have become an effective means of cancer therapy. With the aim of exploring the effective anticancer activity of quercetin, we reevaluated the induction of cell death by quercetin at various concentrations and incubation times and examined the role of autophagy in quercetin-induced apoptosis in p53-mutant U373MG cells. Our results demonstrated for the first time that quercetin suppresses the proliferation of U373MG cells by modulating apoptotic and autophagic fluxes. Quercetin-induced cytotoxicity of U373MG cells was enhanced when autophagy was blocked before quercetin treatment. Thus, inhibiting autophagy must be considered a therapeutic approach to reduce U373MG proliferation and as a promising strategy to sensitize cells to quercetin treatment.

\section{Materials and Methods}

2.1. Reagents. Dulbecco's modified Eagle's medium (DMEM), trypsin-EDTA, fetal bovine serum (FBS), penicillin, streptomycin, Alexa Fluor 488 Goat anti-rabbit $\operatorname{IgG}(\mathrm{H}+\mathrm{L})$, and Hoechst 33342 dye were purchased from Invitrogen Life Technologies, Inc. (Grand Island, NY, USA). Dimethyl sulfoxide (DMSO) and MTT were obtained from Amresco (Cleveland, OH, USA). Quercetin, chloroquine, propidium iodide (PI), acridine orange, and LC3II antibody were purchased from Sigma Chemical Co. (St. Louis, MO, USA). JNK, phospho-JNK, p53, Beclin-1, cytochrome c, cleaved poly(ADP-ribose) polymerase (PARP), and caspase- $3,-7$, and -9 antibodies were acquired from Cell Signaling Technology (Beverly, MA, USA). Polyclonal anti-caspase-8 was purchased from R\&D Systems (Minneapolis, MN, USA). The BD Mitoscreen (JC-1) kit was acquired from BD Biosciences (Franklin Lakes, NJ, USA). A BCA protein assay kit was obtained from Pierce (Rockford, IL, USA), and polyvinylidene fluoride (PVDF) membranes were purchased from Millipore (Bedford, MA, USA). Fluorescence Mounting Medium was purchased from DAKO (Ely, United Kingdom). All other reagents used were of analytical grade.

2.2. Cell Culture. Human glioblastoma U373MG cells were kindly provided by Professor Tae-Hoo Yi at the Department of Biotechnology, Kyunghee University, Republic of Korea [34]. The U373MG cells were cultured in DMEM containing $10 \%(\mathrm{v} / \mathrm{v})$ heat inactivated FBS, 100 units/mL penicillin, and $100 \mu \mathrm{g} / \mathrm{mL}$ streptomycin. The cells were maintained in a humidified $5 \% \mathrm{CO}_{2}$ incubator at $37^{\circ} \mathrm{C}$.

2.3. Cell Viability. The effect of quercetin on U373MG cell viability was determined by an MTT-based assay [35]. Briefly, exponential-phase cells were collected and transferred to a microtiter plate $\left(1 \times 10^{4}\right.$ cells $\left./ \mathrm{mL}\right)$. The cells were incubated with various concentrations of quercetin and/or chloroquine for 24, 48, and $72 \mathrm{~h}$. Then, $0.1 \mathrm{mg}$ of MTT was added to each well and incubated for $4 \mathrm{~h}$ at $37^{\circ} \mathrm{C}$. The medium was removed, and DMSO $(150 \mu \mathrm{L})$ was added to each well to dissolve the formazan crystals. The plates were read immediately at $570 \mathrm{~nm}$ on a Sunrise microplate reader (Tecan, Salzburg, Austria). The percentage of viable cells was calculated based on the following formula: mean value of (control group - treated group/control group) $\times 100 \%$. All results were assessed in triplicate at each concentration.

2.4. Cellular Morphology, Nuclear Fragmentation, and Acidic Vesicular Organelles. U373MG cells were placed in 12-well plates at $3 \times 10^{4}$ cells $/ \mathrm{mL}$ and treated with different concentrations of quercetin and/or pretreated with chloroquine. After 
$48 \mathrm{~h}, 10 \mu \mathrm{M}$ Hoechst 33342, a DNA-specific fluorescent dye or acridine orange, a lysotropic dye, was added to each well, and the plates were incubated for $10 \mathrm{~min}$ at $37^{\circ} \mathrm{C}$. The stained cells were observed under an Olympus fluorescence microscope (Tokyo, Japan).

2.5. Flow Cytometric Analysis. Cells $\left(1 \times 10^{4}\right.$ cells $\left./ \mathrm{mL}\right)$ were plated in $60 \mathrm{~mm}$ plates and treated with quercetin $(0-$ $100 \mu \mathrm{M})$ for $48 \mathrm{~h}$. Then, the cells were harvested, washed with phosphate-buffered saline (PBS), fixed in 70\% ethanol, rehydrated in $2 \mathrm{mM}$ EDTA-PBS, treated with RNase A $(25 \mathrm{ng} / \mathrm{mL})$, and stained with propidium iodide $(40 \mu \mathrm{g} / \mathrm{mL})$ for flow cytometry. The cells were stained with $10 \mu \mathrm{M}$ acridine orange, harvested, and maintained in $2 \mathrm{mM}$ EDTA-PBS containing 10\% FBS to detect autophagy. We followed the manufacturer's protocol for JC-1 mitochondrial membrane detection. In brief, treated cells were trypsinized and washed with $1 \times$ assay buffer, stained with JC- 1 for $15 \mathrm{~min}$ at $37^{\circ} \mathrm{C}$ in a $\mathrm{CO}_{2}$ incubator, and washed twice with $1 \times$ assay buffer at room temperature. All analyses were performed using a FACScaliber flow cytometer (BD Biosciences). Data from 10,000 cells per sample were analyzed with CellQuest software (BD Biosciences). Each experiment was repeated at least three times.

2.6. Caspase Activity. Caspase- 3 and -9 activities were measured using a colorimetric assay following the protocol of the commercially available kit from Sigma Chemical Co. and Biovision (San Jose, CA, USA), respectively. Briefly, cells were lysed after a $48 \mathrm{~h}$ quercetin treatment with or without chloroquine, and aliquots $(10 \mu \mathrm{L})$ of the supernatant were placed in a 96-well microplate containing reaction buffer. Substrate was added, and the microplate was incubated at $37^{\circ} \mathrm{C}$ overnight. Activity was monitored as the linear release of $p$-nitroaniline from the substrate and compared with a linear standard curve generated on the same microplate.

2.7. Cellular Fraction and Immunoblot Analyses. U373MG cells were collected and washed twice with cold PBS after treatment with various quercetin concentrations. The cells were then lysed in lysis buffer $(50 \mathrm{mM}$ Tris- $\mathrm{HCl}, \mathrm{pH} 7.5$, $150 \mathrm{mM} \mathrm{NaCl}, 1 \%$ Nonidet P-40, 2 mM EDTA, 1 mM EGTA, $1 \mathrm{mM} \mathrm{NaVO}_{3}, 10 \mathrm{mM} \mathrm{NaF}, 1 \mathrm{mM}$ DTT, $1 \mathrm{mM}$ PMSF, $25 \mu \mathrm{g} / \mathrm{mL}$ aprotinin, and $25 \mu \mathrm{g} / \mathrm{mL}$ leupeptin) and kept in ice for $30 \mathrm{~min}$. The lysates were centrifuged for $30 \mathrm{~min}$ at $13,000 \mathrm{rpm}$ and $4^{\circ} \mathrm{C}$, and the supernatants were stored at $-70^{\circ} \mathrm{C}$ until use. Cytosolic and mitochondrial extracts were prepared using fraction lysis buffer $\left(75 \mathrm{mM} \mathrm{NaCl}, 8 \mathrm{mM} \mathrm{Na} \mathrm{HPO}_{4}, 1 \mathrm{mM}\right.$ $\mathrm{Na}_{2} \mathrm{H}_{2} \mathrm{PO}_{4}, 250 \mathrm{mM}$ sucrose, $1 \mathrm{mM}$ EDTA, and $350 \mu \mathrm{g} / \mathrm{mL}$ digitonin). Lysed cells were kept in ice for $10 \mathrm{~min}$ and then centrifuged for $15 \mathrm{~min}$ at $15,000 \mathrm{rpm}$ and $4^{\circ} \mathrm{C}$. The supernatant was the cytosolic fraction. After the pellet was washed with lysis buffer, it was lysed in lysis buffer to prepare whole lysates. Protein concentration was measured using a BCA Protein Assay kit. Aliquots of the lysates (30-70 $\mu \mathrm{g}$ protein) were separated via $10-15 \%$ sodium dodecyl sulfatepolyacrylamide gel electrophoresis and transferred onto a PVDF membrane using glycine transfer buffer $(192 \mathrm{mM}$ glycine, $25 \mathrm{mM}$ Tris-HCl, $\mathrm{pH} 8.8$, and 20\% methanol, v/v). After blocking with $5 \%$ nonfat dried milk, the membranes were incubated for $4 \mathrm{~h}$ with primary antibodies, followed by an additional $30 \mathrm{~min}$ incubation with secondary antibodies in milk containing Tris-buffered saline and $0.1 \%$ Tween 20 . Human anti-caspase-3, -caspase-7, -caspase-8, cleaved PARP, cytochrome c, JNK, phospho-JNK, p53, HSP60, LC3II, and Beclin-1 antibodies were used at a 1:1,000 dilution as the primary antibodies, and horseradish peroxidase-conjugated goat antihuman IgG was utilized as the secondary antibody at a 1:5,000 dilution. The membranes were then exposed to $\mathrm{X}$-ray film. Protein bands were detected using the WESTZOL plus Western blot detection system (Intron, Gyeonggido, Republic of Korea).

2.8. Statistical Analysis. All results are expressed as means \pm standard deviations. A one-way analysis of variance was conducted using the SPSS ver. 12.0 for Windows, 2004 package (SPSS Inc., Chicago, IL, USA). $P<0.05$ was considered significant. All assays were performed in triplicate.

\section{Results and Discussion}

3.1. Quercetin Induces Apoptotic U373MG Cell Death. The MTT assay was performed to investigate the cytotoxic effects of quercetin on human glioblastoma U373MG cells. As shown in Figure 1(a), a 48 or $72 \mathrm{~h}$ incubation with quercetin reduced U373MG cell viability in a dose-dependent manner. A significant decrease in cell viability was observed after 48 (27.63\%) and $72 \mathrm{~h}(20.52 \%)$ of incubation at a concentration of $200 \mu \mathrm{M}$, whereas cell viability after a $24 \mathrm{~h}$ incubation was $59.17 \%$ (Figure 1(b)). Various morphological changes such as cell shrinkage and condensation as well as chromatin fragmentation were clearly noted during apoptotic cell death. U373MG cells treated with various concentrations of quercetin were examined by fluorescence microscopy after Hoechst 33342 staining to evaluate the effect of quercetin on the induction of apoptosis. As depicted in Figure 1(b), cells showed marked morphological changes such as condensed and fragmented chromatin and the formation of apoptotic bodies after treatment with $25,50,75$, and $100 \mu \mathrm{M}$ quercetin. Furthermore, the induction of apoptosis was indicated by the accumulation of sub-G1-phase U373MG cells after quercetin treatment. A significant increase in sub-G1-phase cells was not observed in the $24 \mathrm{~h}$ treatment (from $1.02 \%$ at $0 \mu \mathrm{M}$ to $2.05 \%$ at $100 \mu \mathrm{M})$. However, quercetin significantly increased the subG1 population concentration dependently after the $48 \mathrm{~h}$ treatment (from $0.46 \%$ at $0 \mu \mathrm{M}$ to $8.48 \%$ at $100 \mu \mathrm{M}$; Table 1 ). The mitochondrial membrane potential was disrupted as a result of apoptosis (Figure 1(c)) in dose-dependent manner. Because caspases- 9 and -3 are key executioners of apoptosis, we quantified their enzymatic activities using a commercially available kit. As a result, quercetin dose-dependently increased caspase- 9 and -3 activities (Figures $1(\mathrm{~d})$ and 1(e)). These results indicate that quercetin induces apoptosis in U373MG cells via the intrinsic pathway by activating caspase3 and caspase-9. 


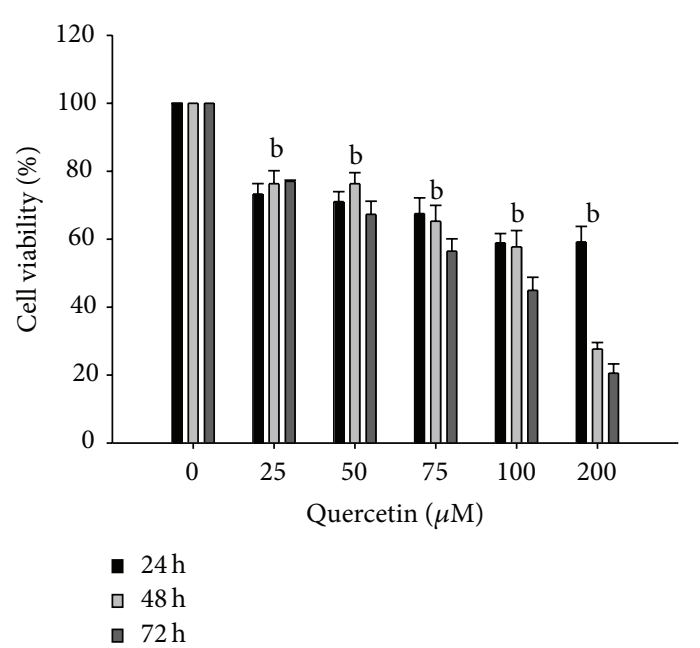

(a)

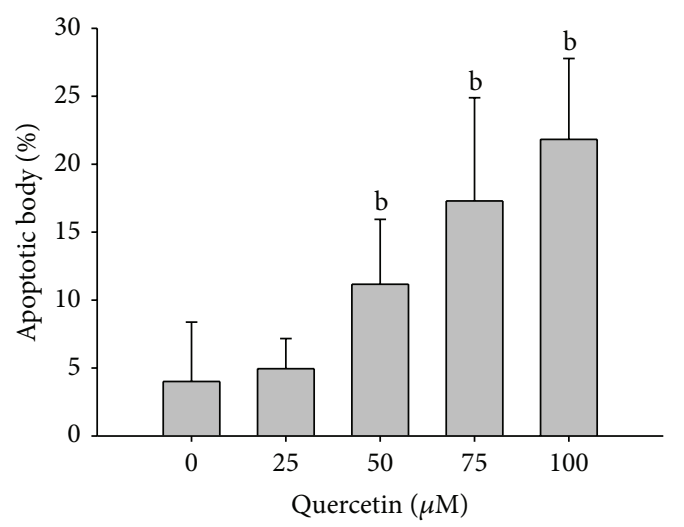

(c)

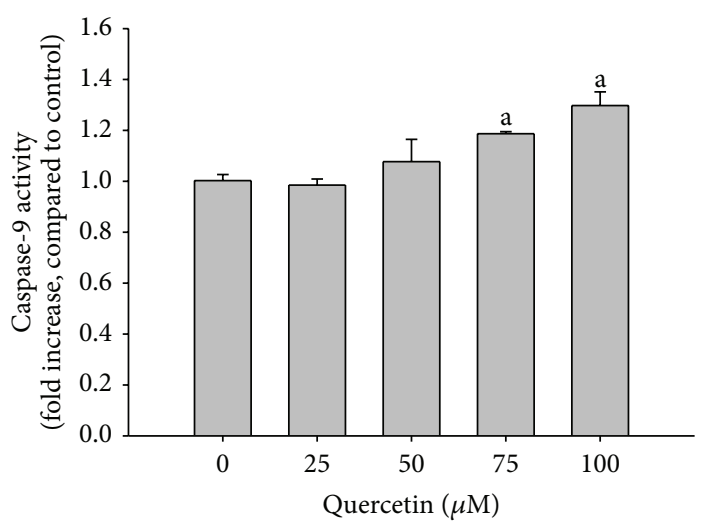

(e)
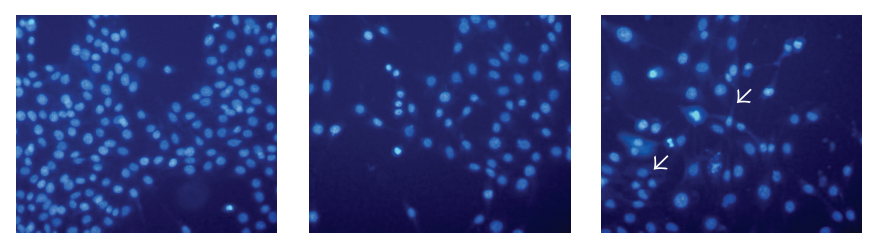

Control

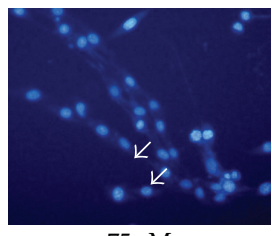

$75 \mu \mathrm{M}$

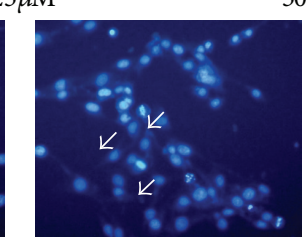

$100 \mu \mathrm{M}$

(b)

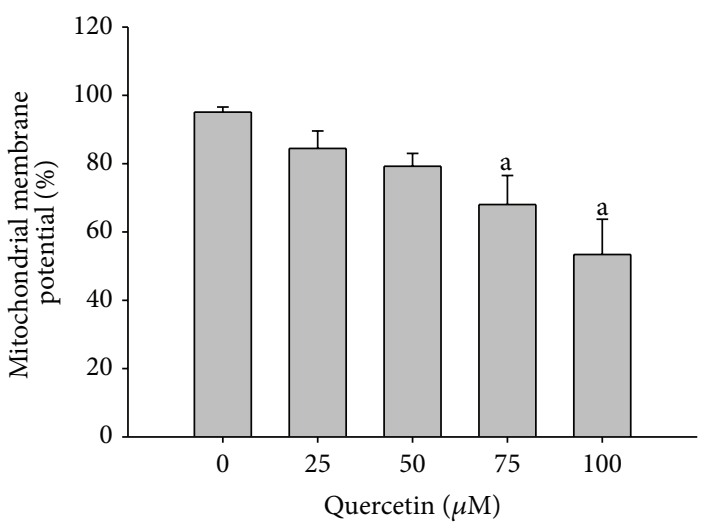

(d)

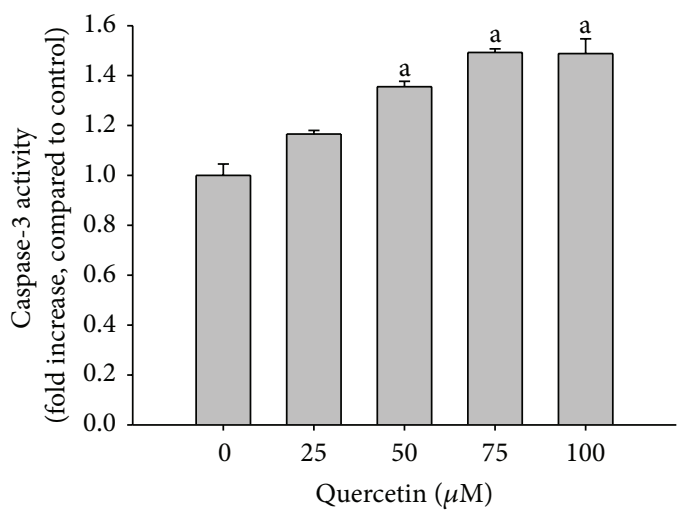

(f)

FIGURE 1: Quercetin inhibits cell growth and induces apoptosis. (a) Cell viability was determined by MTT reduction. U373MG human glioblastoma cells were treated with increasing doses of quercetin for different lengths of time $(24-72 \mathrm{~h})$. Data are the mean \pm standard error for one experiment performed in triplicate. Values are the mean \pm standard deviation (SD) of three independent experiments. ${ }^{\mathrm{b}} P<0.01$ compared to the control. (b) Treated cells were stained with nuclear Hoechst 33342 and visualized under a fluorescence microscope after a $48 \mathrm{~h}$ treatment. White arrows indicate apoptotic bodies. Representative areas were photographed with 200X magnification. (c) Graph for quantification of number of apoptotic bodies. Data are the mean \pm standard error for one experiment performed in triplicate. ${ }^{b} P<0.01$ compared to the control. (d) Flow cytometry analysis of JC-1 staining. Cells were trypsinized, stained with JC-1, washed, and analyzed by flow cytometry. The decrease in mitochondrial membrane potential percentage indicates that cells were undergoing mitochondrial dysfunction. (e) Caspase-9 and (f) caspase-3 activities in U373MG cells. Caspase activities were measured by a colorimetric assay and calculated as fold changes compared to the same control. The cells were treated with quercetin for $48 \mathrm{~h}((\mathrm{~b})-(\mathrm{f}))$. All data are the mean $\pm \mathrm{SD}$ of three independent experiments. a: significantly different from the control, $P<0.05$. 


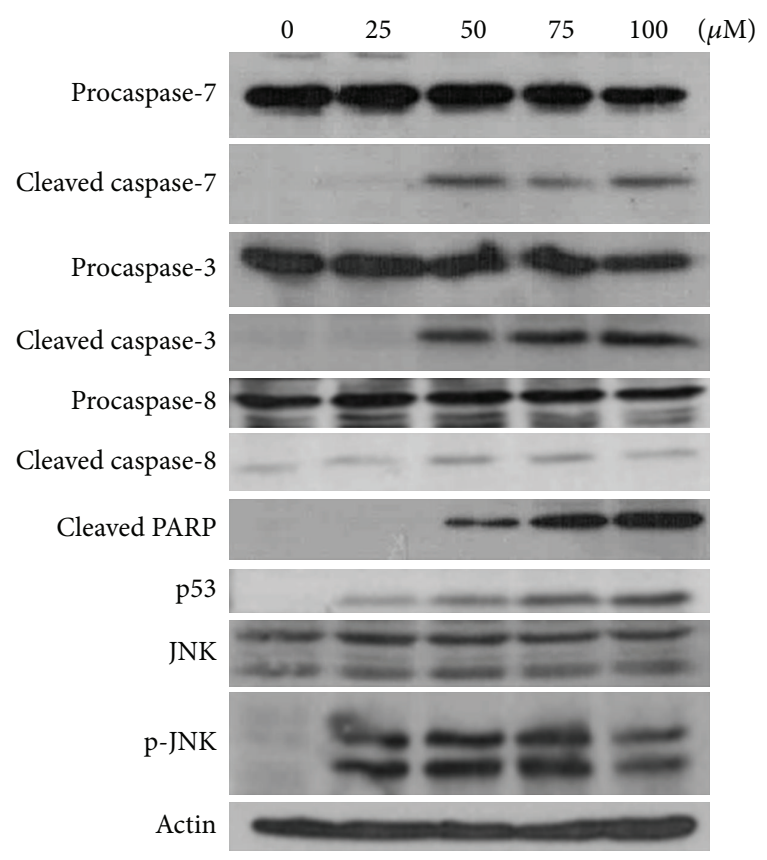

(a)

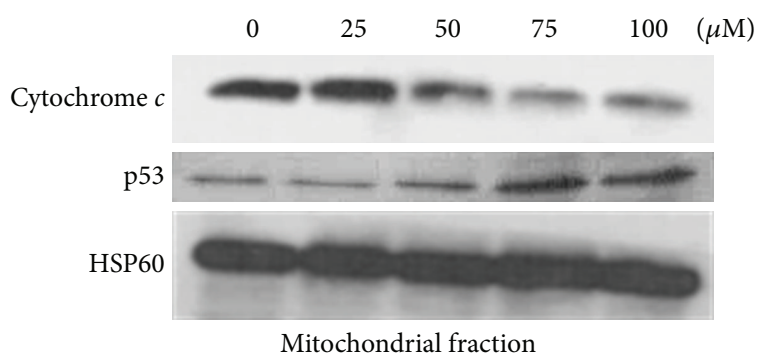

(b)

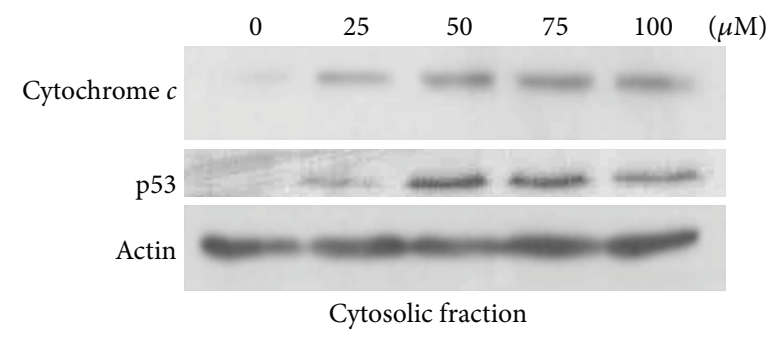

(c)

FIGURE 2: Expression levels of apoptosis-related proteins were analyzed by immunoblotting. (a) Cellular proteins, (b) mitochondrial fraction, and (c) cytosolic fraction were separated by sodium dodecyl sulfate-polyacrylamide gel electrophoresis and transferred to PVDF membranes. The membranes were probed with the indicated primary antibodies and then with horseradish peroxidase conjugated goat anti-rabbit IgG. Heat shock protein (HSP)60 was used as the loading control for the mitochondrial proteins (b). Actin was used as the internal control (a) and loading control for the cytosolic proteins (c).

TABLE 1: The percentage of U373MG cells in the sub-G1 fraction after treatment with different doses of quercetin for 24 and $48 \mathrm{~h}$.

\begin{tabular}{lcc}
\hline Concentration $(\mu \mathrm{M})$ & $\begin{array}{c}24 \mathrm{~h} \\
\text { Sub-G1 phase }(\%)\end{array}$ & $\begin{array}{c}48 \mathrm{~h} \\
\text { Sub-G1 phase }(\%)\end{array}$ \\
\hline Control & $1.02 \pm 0.35$ & $0.5 \pm 0.31$ \\
25 & $1.78 \pm 0.89$ & $1.71 \pm 0.53$ \\
50 & $2.33 \pm 1.17$ & $2.26 \pm 0.86$ \\
75 & $1.65 \pm 0.65$ & $6.66 \pm 0.79^{\mathrm{a}}$ \\
100 & $2.05 \pm 0.93$ & $8.48 \pm 0.40^{\mathrm{a}}$ \\
\hline
\end{tabular}

All data are the mean \pm SD of three independent experiments. ${ }^{a}$ Significantly different from the control, $P<0.05$.

3.2. Effects of Quercetin on Apoptosis-Related Protein Expression. The expression of apoptosis-related proteins and activation of caspases following quercetin treatment were examined by Western blotting to further determine the mechanism of quercetin-induced apoptosis. The protein level of the caspase7 and -3 precursor decreased, and proteolytically cleaved caspase- 7 and -3 as well as PARP levels increased, although not much change was observed in the caspase- 8 level (Figure 2(a)). JNK was activated, and p53 protein and phosphorylation levels dose-dependently increased following quercetin treatment (Figure 2(a)). JNK is one of the mitogenactivated protein kinases (MAPKs) that regulate cell proliferation, differentiation, and apoptosis [36]. JNK directly or indirectly modulates the expression levels of p53 and its target genes [37]. Evidence suggests that p53 induces cell death by several molecular pathways involving the activation of target genes and transcriptionally independent direct signaling [21]. In our study, p53 expression increased concentration dependently, but the level of the p53 downstream protein, PUMA, remained unchanged (data not shown) because U373MG is a p53 mutant cell line. Our result suggests that mutant p53 in U373MG cells can induce apoptosis through a transcriptionindependent pathway, as the level of cytochrome $\mathrm{c}$ increased in the cytosolic fraction, whereas the level of cytochrome c decreased in the mitochondrial fraction (Figures 2(b) and $2(c))$ with a decrease in mitochondrial membrane potential (Figure 1(c)). Although additional experiments are required to determine whether the $\mathrm{p} 53-\mathrm{Bcl}-2 / \mathrm{xL}$ interaction occurs to fully understand quercetin-induced death of the p53 mutant glioblastoma-derived cell U373MG cells, we speculate that our results are similar to previous data in C33A cells in which the p53 mutant was transiently located to the mitochondria with changes in the mitochondrial membrane potential [27].

3.3. Quercetin Induces Autophagy in U373MG Cells. We examined the effects of quercetin on other cellular responses associated with cell death to better understand its anticancer effect. Acridine orange staining was used to analyze the formation of acidic vesicular organelles (AVOs) or autophagolysosome vacuoles, which occur as a result of fusion between autophagosomes and lysosomes as a key feature of autophagy [38]. Large numbers of AVOs were detected in 

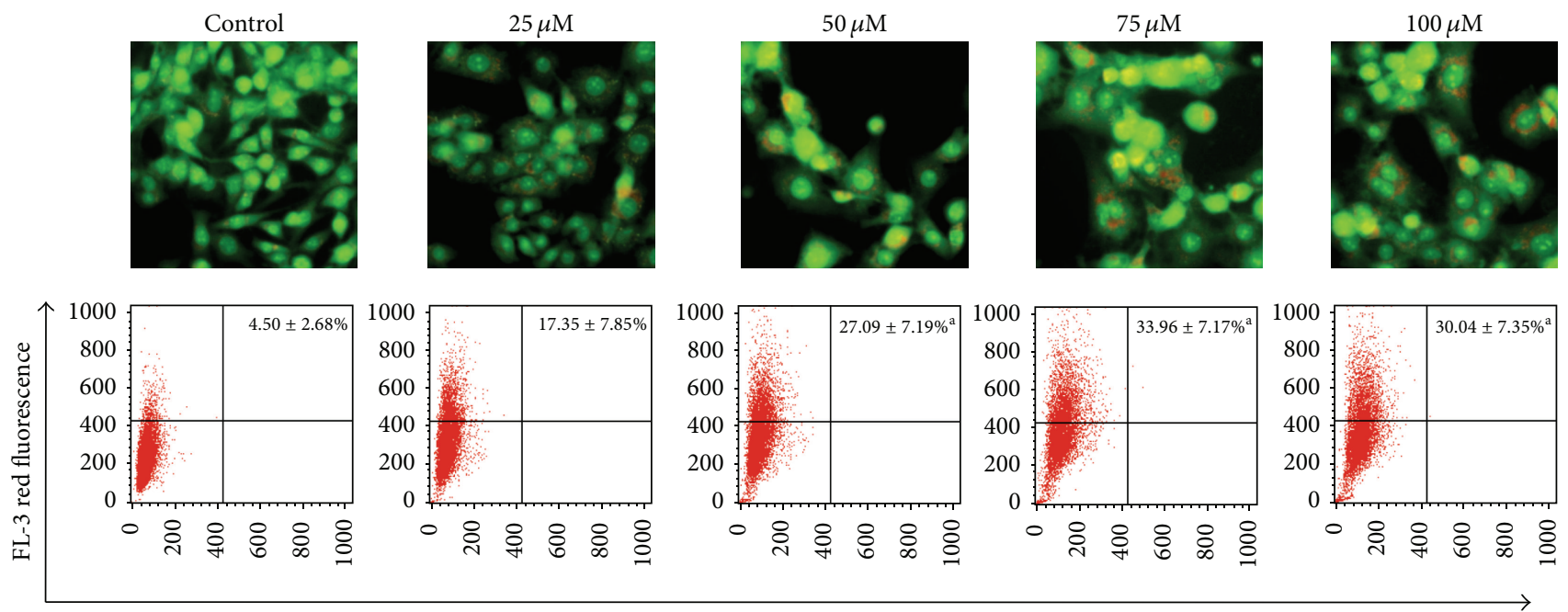

FL-1 green fluorescence

(a)

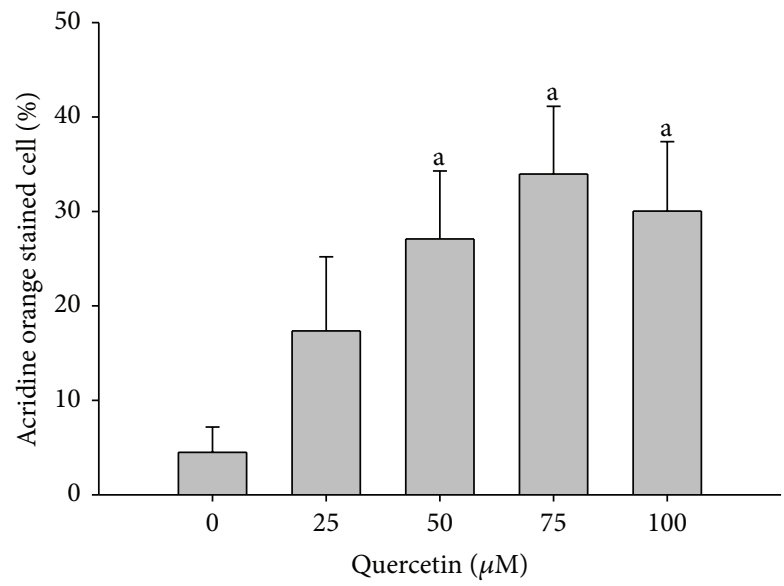

(b)

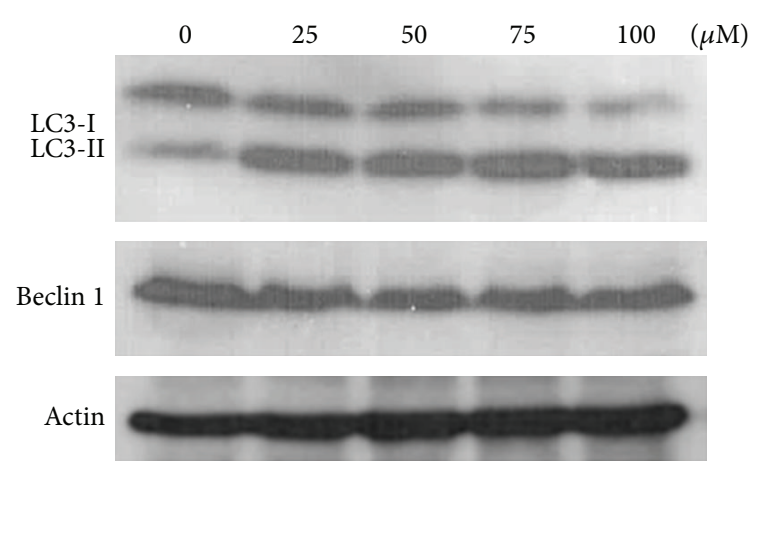

(c)

FIGURE 3: Quercetin induces autophagy in U373MG cells. The cells were treated with various concentrations of quercetin for $48 \mathrm{~h}$. (a) Analysis of the formation of autophagosomes and autolysosomes by fluorescence microscopy and flow cytometry. Representative areas were photographed with 200X magnification. (b) Quantification of acridine orange-positive cells. (c) Western blotting using antibodies specific for LC3, Beclin-1, and actin. Results shown are representative of three independent experiments. Images were captured using a fluorescence microscope. Results shown are representative of at least three replicates. All data are the mean \pm standard deviation of three independent experiments. a, significantly different from the control, $P<0.05$.

U373MG cells treated with quercetin (Figure 3(a)). The FACS analysis showed that AVOs formed in $17.35 \%$ of U373MG cells treated with $25 \mu \mathrm{M}$ quercetin and in $33.9 \%$ of U373MG cells treated with $75 \mu \mathrm{M}$ quercetin and that a slight decrease (30.04\%) occurred in U373MG cells treated with $100 \mu \mathrm{M}$ quercetin (Figure 3(b)). These data are consistent with the results of our Western blot analysis of the autophagy marker protein LC3. Conversion of the lipidated form of LC3 (LC3I) to LC3-II, which is an autophagosomal marker, is due to localization and aggregation of LC3-II in autophagosomes [39]. Quercetin induced the processing of full-length LC3I $(18 \mathrm{kDa})$ to LC3-II $(16 \mathrm{kDa})$ dose-dependently at concentrations up to $75 \mu \mathrm{M}$, but a slight decrease was observed in $100 \mu \mathrm{M}$ treated cells (Figure 3(c)). These results indicate that autophagy is less predominant in U373MG cells treated with a high concentration of quercetin. In contrast to LC3, Beclin-1 expression remained unchanged (Figure 3(c)). Although Beclin-1 plays an important role in autophagy, several studies have revealed that autophagy can occur in a Beclin-1-independent manner [40, 41]. We analyzed the cells stained with fluorescent LC3 antibodies to confirm that quercetin induced autophagy. Quercetin reportedly can induce autophagy in many different cell lines such as gastric, bladder, and colon cancer cell lines [6, 42, 43]. However, a recent study reported that quercetin significantly induces apoptosis but has no effect on inducing autophagy in the T98G glioma cell line [44], highlighting the heterogeneity of glioma cell biology; therefore, comprehensive multicell line studies are needed. P53 typically regulates autophagy via transcription-dependent and -independent mechanisms. A 

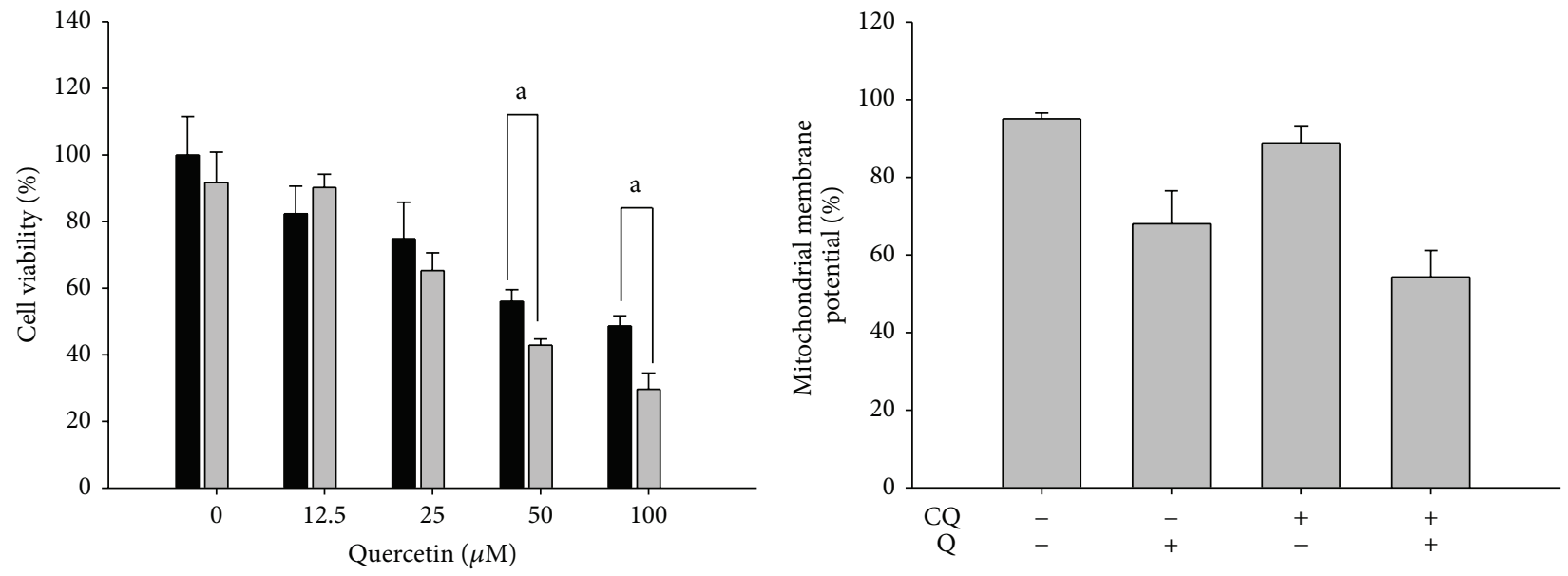

Quercetin alone

Quercetin with chloroquine

(a)

(b)
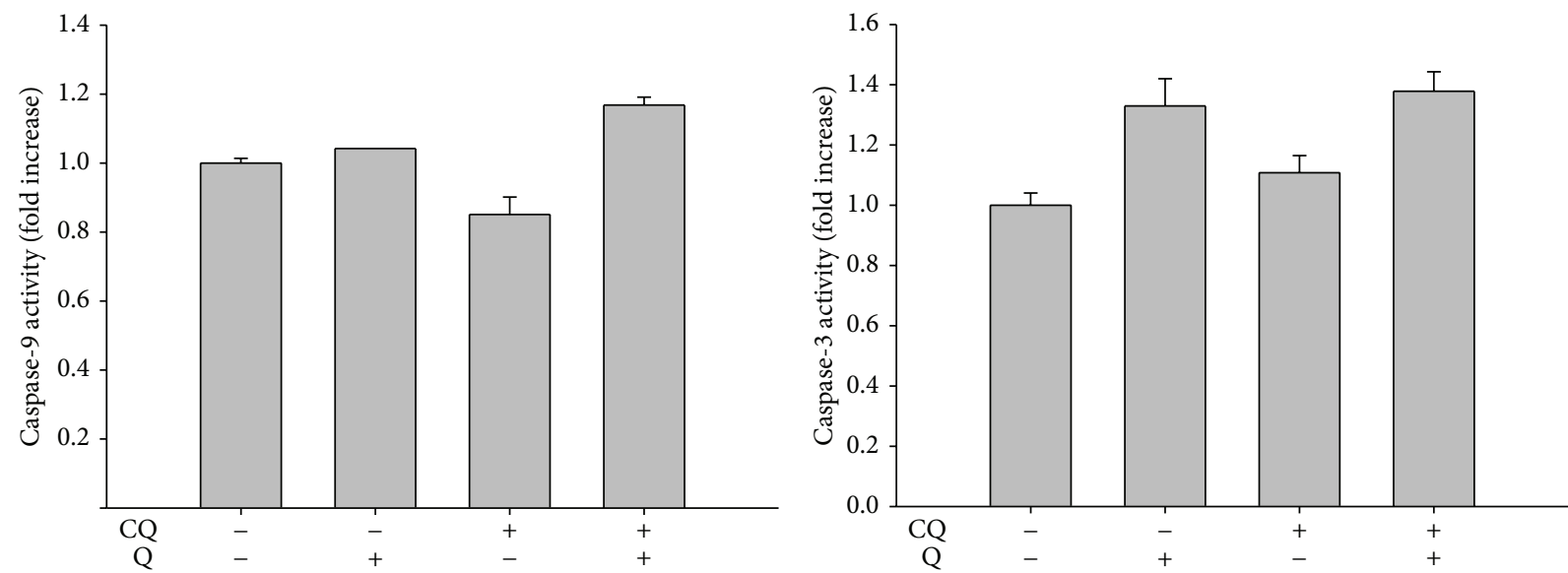

(c)

(d)

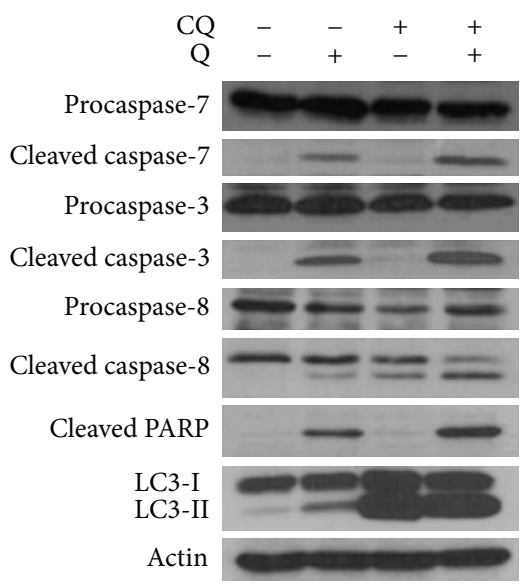

(e)

FIGURE 4: Inhibition of autophagy by chloroquine enhances apoptotic cell death. Cells were treated with $50 \mu \mathrm{M}$ chloroquine for $2 \mathrm{~h}$ before quercetin treatment. (a) Cell viability was measured by the MTT assay. Values are the mean \pm standard deviation (SD) of three independent experiments. a: significantly different from the control, $P<0.05$; b: significantly different from the control, $P<0.01$. (b) The percentage of cells undergoing mitochondrial dysfunction. Treated cells were trypsinized, stained with JC-1, washed, and analyzed by flow cytometry. (c) Caspase- 9 and (d) caspase- 3 activities. All data are the mean \pm SD of three independent experiments. a: significantly different from the control, $P<0.05$. (e) Analysis of apoptosis-related protein and LC3II expression by Western blotting. CQ: $50 \mu \mathrm{M}$ chloroquine; Q: $75 \mu \mathrm{M}$ quercetin. 
TABLE 2: The percentage of U373MG cells in the sub-G1 fraction after treatment with $75 \mu \mathrm{M}$ quercetin alone for $48 \mathrm{~h}, 50 \mu \mathrm{M}$ chloroquine alone for $2 \mathrm{~h}$, or quercetin for $48 \mathrm{~h}$ plus pretreatment with chloroquine for $2 \mathrm{~h}$.

\begin{tabular}{lc}
\hline Treatment & Sub-G1 phase (\%) \\
\hline Control & $2.21 \pm 1.1$ \\
Quercetin alone & $1.45 \pm 0.21$ \\
Chloroquine alone & $5.18 \pm 0.96$ \\
Chloroquine + quercetin & $18.68 \pm 3.02$ \\
\hline
\end{tabular}

spectrum of p53 target genes such as DRAM and AMPK positively regulates autophagy in a transcription-dependent manner [45]. However, several studies have reported that cytoplasmic p53 inhibits autophagy in a transcriptionindependent manner through a poorly investigated mechanism [46-48]. Further investigation is required to determine whether increase in the cytosolic mutant p53 following quercetin treatment in U373MG cells represses autophagy and promotes apoptosis through translocation to mitochondria.

3.4. Inhibition of Autophagy by Chloroquine Promotes U373MG Cell Apoptosis. Several studies have shown that autophagy and apoptosis interact. Some proteins, already known as autophagy proteins, have dual functions in autophagy and apoptosis $[4,35]$. To further analyze whether the autophagy signal induced by quercetin is prosurvival or prodeath, we treated U373MG cells with chloroquine, an inhibitor of autophagy, for $2 \mathrm{~h}$ before quercetin treatment. Chloroquine induces apoptosis in glioma cell lines via the p53 pathway [49]. The chloroquine treatment alone showed no effect on cell viability but a combined treatment with quercetin decreased cell viability compared to that of quercetin treatment alone (Figure 4(a)). Furthermore, pretreatment with chloroquine plus quercetin resulted in significant sub-G1 phase cell cycle arrest; the percentage of sub-G1 cells was $1.45 \%, 5.18 \%$, and $18.68 \%$, in U373MG cells treated with quercetin alone, chloroquine alone, and pretreated with chloroquine plus quercetin, respectively (Table 2 ). The mitochondrial membrane potential values were $68.0 \%$ and $54.3 \%$ following treatment with $75 \mu \mathrm{M}$ quercetin alone and after pretreatment with chloroquine plus quercetin, respectively (Figure 4(b)). Caspase-9 and -3 activities increased slightly in the combined treatment compared to those of quercetin treatment alone (Figures 4(c) and 4(d)). Western blot results showed a similar tendency in the cell cycle distribution. We also confirmed that inhibiting autophagy promoted apoptosis by increasing cleavage of caspases-3 and -7 and PARP (Figure 4(e)). In particular, the proteolytic cleavage of procaspase- 8 , which was not detected following quercetin treatment alone, rose after chloroquine pretreatment. Taken together, these data strongly suggest that inhibiting autophagy enhances apoptotic cell death induced by quercetin in U373MG cells.

\section{Conclusion}

We demonstrated that quercetin induced cell death in the human glioblastoma U373MG cell line through an apoptotic pathway, which was confirmed by cleavage of caspases, PARP, and sub-G1 phase cell cycle arrest. Quercetin also activated JNK and modulated p53 expression accompanied by increased translocation of p53 to the mitochondria. The induction of autophagy in U373MG glioblastoma cells by quercetin was confirmed through acridine orange staining and conversion of LC3II. Furthermore, pretreatment with chloroquine enhanced intrinsic and extrinsic apoptotic cell death induced by quercetin, indicating that quercetin induced protective autophagy in U373MG cells. These results suggest that quercetin, in a combined treatment with an autophagy inhibitor, may be an excellent therapeutic approach to reduce U373MG proliferation and could be a promising strategy to sensitize cells to quercetin treatment.

\section{Acknowledgments}

This research was supported by the Bio-Industry Technology Development Program, Ministry for Food, Agriculture, Forestry and Fisheries (110137-3), and the Basic Science Research Program through the National Research Foundation of Korea (NRF) funded by the Ministry of Education (2013R1A1A2A10012017), Republic of Korea.

\section{References}

[1] C. Brennan, H. Momota, D. Hambardzumyan et al., "Glioblastoma subclasses can be defined by activity among signal transduction pathways and associated genomic alterations," PLoS ONE, vol. 4, no. 11, Article ID e7752, 2009.

[2] R. Stupp, W. P. Mason, M. J. van den Bent et al., "Radiotherapy plus concomitant and adjuvant temozolomide for glioblastoma," The New England Journal of Medicine, vol. 352, no. 10, pp. 987-996, 2005.

[3] A. Murakami, H. Ashida, and J. Terao, "Multitargeted cancer prevention by quercetin," Cancer Letters, vol. 269, no. 2, pp. 315325, 2008.

[4] T. Chen, J. Jeng, C. Lin, C. Wu, and Y. Chen, "Quercetin inhibition of ROS-dependent and -independent apoptosis in rat glioma C6 cells," Toxicology, vol. 223, no. 1-2, pp. 113-126, 2006.

[5] S. Shen, Y. Chen, F. Hsu, and W. Lee, "Differential apoptosisinducing effect of quercetin and its glycosides in human promyeloleukemic HL-60 cells by alternative activation of the caspase 3 cascade," Journal of Cellular Biochemistry, vol. 89, no. 5, pp. 1044-1055, 2003.

[6] K. Wang, R. Liu, J. Li et al., "Quercetin induces protective autophagy in gastric cancer cells: Involvement of Akt-mTOR- and hypoxia-induced factor $1 \alpha$-mediated signaling," Autophagy, vol. 7, no. 9, pp. 966-978, 2011.

[7] P. Wang, K. Zhang, Q. Zhang et al., "Effects of quercetin on the apoptosis of the human gastric carcinoma cells," Toxicology in Vitro, vol. 26, no. 2, pp. 221-228, 2012.

[8] Y. Chang, Y. Hsu, H. Hung et al., "Quercetin induces oxidative stress and potentiates the apoptotic action of 2-methoxyestradi$\mathrm{ol}$ in human hepatoma cells," Nutrition and Cancer, vol. 61, no. 5, pp. 735-745, 2009. 
[9] E. J. Choi, S. M. Bae, and W. S. Ahn, "Antiproliferative effects of quercetin through cell cycle arrest and apoptosis in human breast cancer MDA-MB-453 cells," Archives of Pharmacal Research, vol. 31, no. 10, pp. 1281-1285, 2008.

[10] C. Chou, J. Yang, H. Lu et al., "Quercetin-mediated cell cycle arrest and apoptosis involving activation of a caspase cascade through the mitochondrial pathway in human breast cancer MCF-7 cells," Archives of Pharmacal Research, vol. 33, no. 8, pp. 1181-1191, 2010.

[11] T. Kawahara, N. Kawaguchi-Ihara, Y. Okuhashi, M. Itoh, N. Nara, and S. Tohda, "Cyclopamine and quercetin suppress the growth of leukemia and lymphoma cells," Anticancer Research, vol. 29, no. 11, pp. 4629-4632, 2009.

[12] H. Yuan, C. Y. F. Young, Y. Tian, Z. Liu, M. Zhang, and H. Lou, "Suppression of the androgen receptor function by quercetin through protein-protein interactions of Spl, c-Jun, and the androgen receptor in human prostate cancer cells," Molecular and Cellular Biochemistry, vol. 339, no. 1-2, pp. 253-262, 2010.

[13] E. Pozsgai, S. Bellyei, A. Boronkai et al., "Quercetin increases the efficacy of glioblastoma treatment compared to standard chemoradiotherapy by the suppression of PI-3-Kinase-Akt pathway," Nutrition and Cancer, vol. 65, no. 7, pp. 1059-1066, 2013.

[14] E. J. Kim, C. H. Choi, J. Y. Park, S. K. Kang, and Y. K. Kim, "Underlying mechanism of quercetin-induced cell death in human glioma cells," Neurochemical Research, vol. 33, no. 6, pp. 971-979, 2008.

[15] J. Michaud-Levesque, N. Bousquet-Gagnon, and R. Béliveau, "Quercetin abrogates IL-6/STAT3 signaling and inhibits glioblastoma cell line growth and migration," Experimental Cell Research, vol. 318, no. 8, pp. 925-935, 2012.

[16] E. Braganhol, L. L. Zamin, A. D. Canedo et al., "Antiproliferative effect of quercetin in the human U138MG glioma cell line," AntiCancer Drugs, vol. 17, no. 6, pp. 663-671, 2006.

[17] M. D. Siegelin, D. E. Reuss, A. Habel, A. Rami, and A. von Deimling, "Quercetin promotes degradation of survivin and thereby enhances death-receptor-mediated apoptosis in glioma cells," Neuro-Oncology, vol. 11, no. 2, pp. 122-131, 2009.

[18] T. Tokino and Y. Nakamura, "The role of p53-target genes in human cancer," Critical Reviews in Oncology/Hematology, vol. 33, no. 1, pp. 1-6, 2000.

[19] U. M. Moll and A. Zaika, "Nuclear and mitochondrial apoptotic pathways of p53," FEBS Letters, vol. 493, no. 2-3, pp. 65-69, 2001.

[20] P. Li, R. Dietz, and R. von Harsdorf, "p53 regulates mitochondrial membrane potential through reactive oxygen species and induces cytochrome c-independent apoptosis blocked by Bcl2," The EMBO Journal, vol. 18, no. 21, pp. 6027-6036, 1999.

[21] N. D. Marchenko, A. Zaika, and U. M. Moll, "Death signalinduced localization of $\mathrm{p} 53$ protein to mitochondria: a potential role in apoptotic signaling," The Journal of Biological Chemistry, vol. 275, no. 21, pp. 16202-16212, 2000.

[22] S. Erster, M. Mihara, R. H. Kim, O. Petrenko, and U. M. Moll, "In vivo mitochondrial p53 translocation triggers a rapid first wave of cell death in response to DNA damage that can precede p53 target gene activation," Molecular and Cellular Biology, vol. 24, no. 15, pp. 6728-6741, 2004.

[23] K. Heyne, K. Schmitt, D. Mueller, V. Armbruester, P. Mestres, and K. Roemer, "Resistance of mitochondrial p53 to dominant inhibition," Molecular Cancer, vol. 7, article 54, 17 pages, 2008.

[24] X. Tang, Y. Zhu, L. Han et al., "CP-31398 restores mutant p53 tumor suppressor function and inhibits UVB-induced skin carcinogenesis in mice," The Journal of Clinical Investigation, vol. 117, no. 12, pp. 3753-3764, 2007.
[25] M. Mahyar-Roemer, C. Fritzsche, S. Wagner, M. Laue, and K. Roemer, "Mitochondrial p53 levels parallel total p53 levels independent of stress response in human colorectal carcinoma and glioblastoma cells," Oncogene, vol. 23, no. 37, pp. 6226-6236, 2004.

[26] M. Mihara, S. Erster, A. Zaika et al., "p53 has a direct apoptogenic role at the mitochondria," Molecular Cell, vol. 11, no. 3, pp. 577-590, 2003.

[27] J. F. Charlot, J. L. Prétet, C. Haughey, and C. Mougin, "Mitochondrial translocation of p53 and mitochondrial membrane potential $(\Delta \Psi \mathrm{m})$ dissipation are early events in staurosporineinduced apoptosis of wild type and mutated p53 epithelial cells," Apoptosis, vol. 9, no. 3, pp. 333-343, 2004.

[28] E. C. Pietsch, E. Perchiniak, A. A. Canutescu, G. Wang, R. L. Dunbrack, and M. E. Murphy, "Oligomerization of BAK by p53 utilizes conserved residues of the p53 DNA binding domain," The Journal of Biological Chemistry, vol. 283, no. 30, pp. 2129421304, 2008.

[29] Z. Yang and D. J. Klionsky, "Mammalian autophagy: core molecular machinery and signaling regulation," Current Opinion in Cell Biology, vol. 22, no. 2, pp. 124-131, 2010.

[30] P. Boya, R. González-Polo, N. Casares et al., "Inhibition of macroautophagy triggers apoptosis," Molecular and Cellular Biology, vol. 25, no. 3, pp. 1025-1040, 2005.

[31] M. M. Hippert, P. S. O’Toole, and A. Thorburn, "Autophagy in cancer: good, bad, or both?" Cancer Research, vol. 66, no. 19, pp. 9349-9351, 2006.

[32] J. J. Lum, D. E. Bauer, M. Kong et al., "Growth factor regulation of autophagy and cell survival in the absence of apoptosis," Cell, vol. 120, no. 2, pp. 237-248, 2005.

[33] M. C. Maiuri, E. Zalckvar, A. Kimchi, and G. Kroemer, "Selfeating and self-killing: crosstalk between autophagy and apoptosis," Nature Reviews Molecular Cell Biology, vol. 8, no. 9, pp. 741-745, 2007.

[34] J. Y. Shin, J. M. Lee, H. S. Shin et al., "Anti-cancer effect of ginsenoside F2 against glioblastoma multiforme in xenograft model in SD rats," Journal of Ginseng Research, vol. 36, no. 1, pp. 86-92, 2012.

[35] J. Carmichael, W. G. DeGraff, and A. F. Gazdar, "Evaluation of a tetrazolium-based semiautomated colorimetric assay: assessment of chemosensitivity testing," Cancer Research, vol. 47, no. 4, pp. 936-942, 1987.

[36] D. N. Dhanasekaran and E. P. Reddy, "JNK signaling in apoptosis," Oncogene, vol. 27, no. 48, pp. 6245-6251, 2008.

[37] M. N. Saha, H. Jiang, Y. Yang et al., “Targeting p53 via JNK pathway: a novel role of RITA for apoptotic signaling in multiple myeloma," PLoS ONE, vol. 7, no. 1, Article ID e30215, 2012.

[38] T. Kanzawa, I. M. Germano, T. Komata, H. Ito, Y. Kondo, and S. Kondo, "Role of autophagy in temozolomide-induced cytotoxicity for malignant glioma cells," Cell Death and Differentiation, vol. 11, no. 4, pp. 448-457, 2004.

[39] Y. Zhang, Y. Wu, S. Tashiro, S. Onodera, and T. Ikejima, "Reactive oxygen species contribute to oridonin-induced apoptosis and autophagy in human cervical carcinoma HeLa cells," Acta Pharmacologica Sinica, vol. 32, no. 10, pp. 1266-1275, 2011.

[40] S. Tian, J. Lin, J. Zhou et al., "Beclin 1-independent autophagy induced by a Bcl-XL/Bcl-2 targeting compound, Z18," Autophagy, vol. 6, no. 8, pp. 1032-1041, 2010.

[41] F. Scarlatti, R. Maffei, I. Beau, P. Codogno, and R. Ghidoni, "Role of non-canonical Beclin 1-independent autophagy in cell death induced by resveratrol in human breast cancer cells," Cell Death and Differentiation, vol. 15, no. 8, pp. 1318-1329, 2008. 
[42] L. Wei, J. J. Liu, J. Cao, N. C. Du, L. N. Ji, and X. L. Yang, "Role of autophagy in quercetin-induced apoptosis in human bladder carcinoma BIU-87 cells," Zhonghua Zhong Liu Za Zhi, vol. 34, no. 6, pp. 414-418, 2012.

[43] F. H. Psahoulia, S. Moumtzi, M. L. Roberts, T. Sasazuki, S. Shirasawa, and A. Pintzas, "Quercetin mediates preferential degradation of oncogenic Ras and causes autophagy in HaRAS-transformed human colon cells," Carcinogenesis, vol. 28, no. 5, pp. 1021-1031, 2007.

[44] J. Jakubowiez-Gil, E. Langner, D. Badziul, I. Wertel, and W. Rzeski, "Apoptosis induction in human glioblastoma multiforme T98G cells upon temozolomide and quercetin treatment," Tumor Biology, vol. 34, no. 4, pp. 2367-2378, 2013.

[45] Z. Feng, H. Zhang, A. J. Levine, and S. Jin, "The coordinate regulation of the $\mathrm{p} 53$ and mTOR pathways in cells," Proceedings of the National Academy of Sciences of the United States of America, vol. 102, no. 23, pp. 8204-8209, 2005.

[46] E. Morselli, E. Tasdemir, M. C. Maiuri et al., "Mutant p53 protein localized in the cytoplasm inhibits autophagy," Cell Cycle, vol. 7, no. 19, pp. 3056-3061, 2008.

[47] D. R. Green and G. Kroemer, "Cytoplasmic functions of the tumour suppressor p53," Nature, vol. 458, no. 7242, pp. 11271130, 2009.

[48] K. M. Ryan, "P53 and autophagy in cancer: guardian of the genome meets guardian of the proteome," European Journal of Cancer, vol. 47, no. 1, pp. 44-50, 2011.

[49] E. L. Kim, R. Wustenberg, A. R. Ubsam et al., "Chloroquine activates the p53 pathway and induces apopotosis in human glioma cells," Neuro-Oncology, vol. 12, no. 4, pp. 389-400, 2010. 


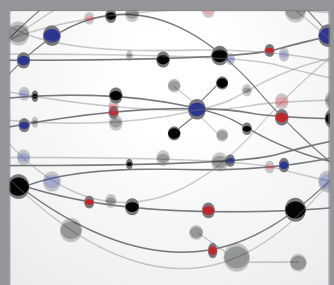

The Scientific World Journal
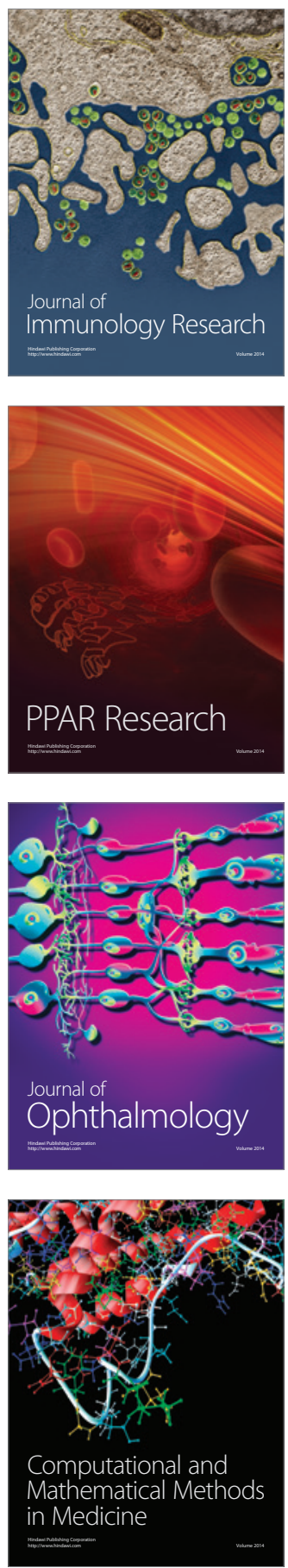

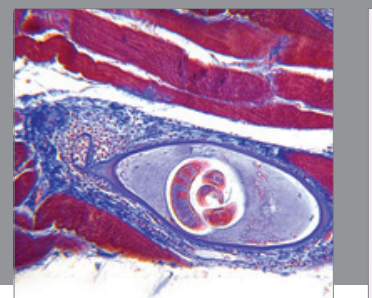

Gastroenterology

Research and Practice
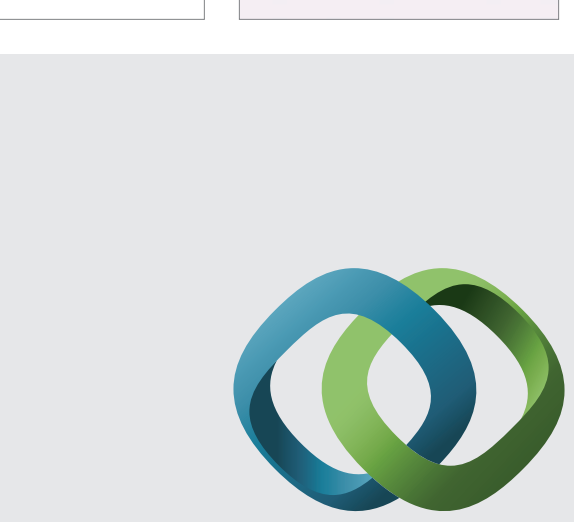

\section{Hindawi}

Submit your manuscripts at

http://www.hindawi.com
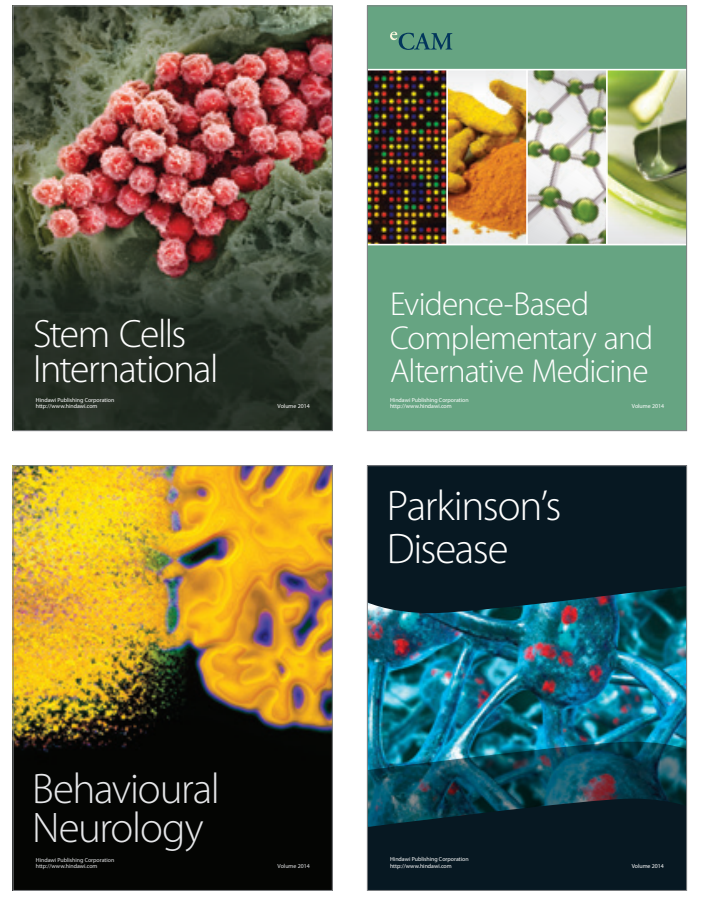
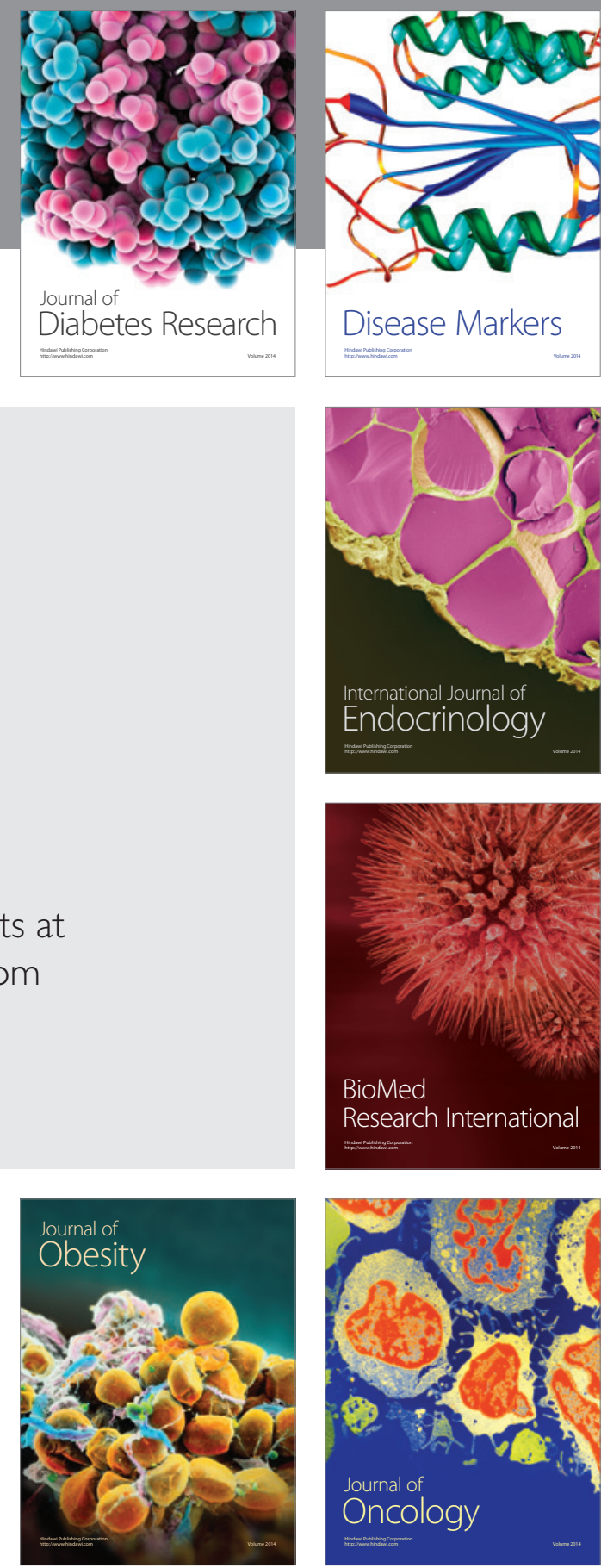

Disease Markers
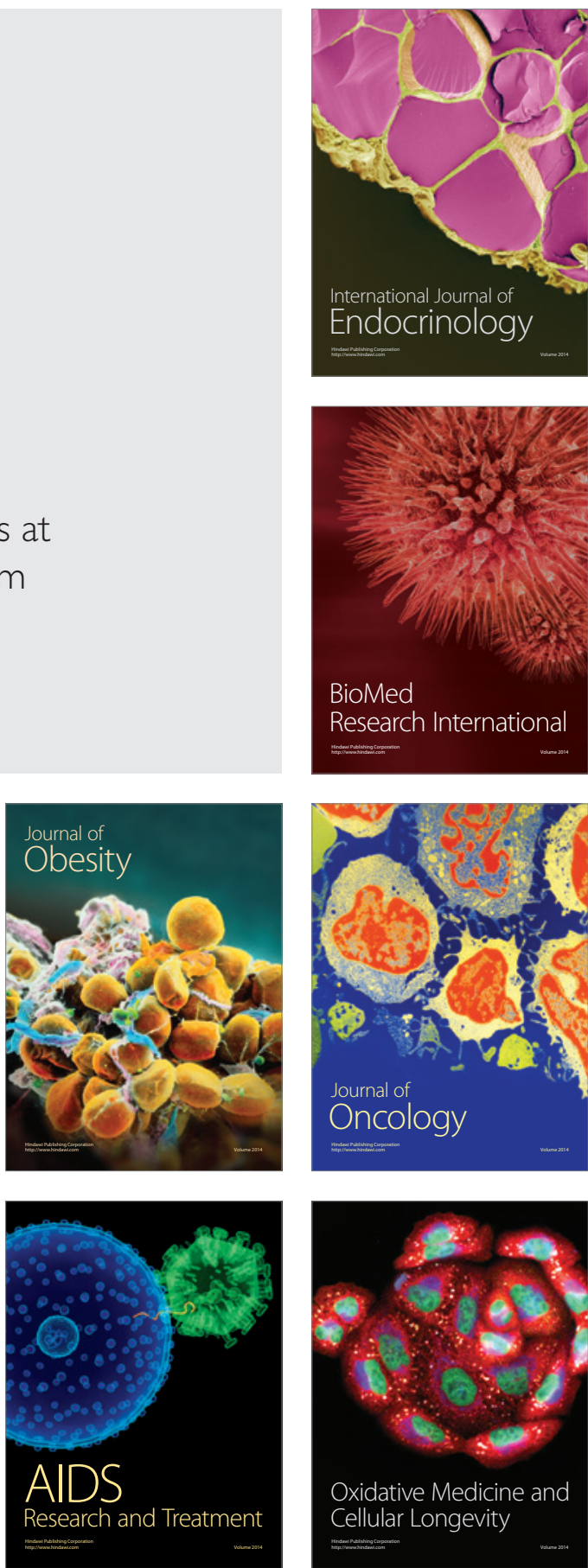